\title{
Gastrophysa viridula (Coleoptera: Chrysomelidae) in the Czech Republic: Decline in a once abundant invasive oligophagous consumer of Rumex
}

\author{
Zdenka MARtinkova iD, Alois honek iD and Pavel SASKA iD \\ Crop Research Institute, Drnovska 507, 16106 Praha 6 - Ruzyne, Czech Republic; e-mails: martinkova@vurv.cz, \\ honek@vurv.cz, saska@vurv.cz
}

Key words. Chrysomelidae, Gastrophysa viridula, green dock beetle, abundance, decline, herbivore, control of Rumex, Czech Republic

\begin{abstract}
While the progress of the spread of invasive species of insects in new geographical areas are usually intensively monitored, the decline of these species often escape attention and is poorly documented. In this study, we record the decline in abundance of Gastrophysa viridula (DeGeer), an invasive oligophagous consumer of dock (Rumex spp.). This species originally inhabited Alpine regions. In the late 1800s, G. viridula was recorded in montane areas in the Czech Republic and then throughout this country. Gastrophysa viridula was very abundant in 1995-1999, when we found it in all of the 177 stands of $R$. obtusifolius inspected in western Czech Republic. In a repeated study of its occurrence in the same area from 2019-2020, this species was present in $<30 \%$ of 434 of the stands inspected and was only abundant ( $\geq 55 \%$ of plants in the stand infested by G. viridula) in $<4 \%$ of these stands. Thus the local occurrence and abundance of $G$. viridula had decreased significantly. Of the possible reasons for this decline the most probable are the effect of climate warming on host plant seasonality, changes in agricultural use of grasslands and fragmentation of large stands of dock.
\end{abstract}

\section{INTRODUCTION}

Invasion, an encroachment of a species from one area into another (Lincoln et al., 1998), is an intensively studied ecological phenomenon. These species often have a marked effect on native ecosystems in newly colonized areas (Bradshaw et al., 2016) and sometimes negative economic consequences (Kenis et al., 2009). Therefore, the colonization by a species of a new geographical area is often quickly detected and carefully monitored (Roy et al., 2019). In contrast, the decline of a species can escape attention, even if the species is abundant and economically important.

Gastrophysa viridula (DeGeer) (Coleoptera: Chrysomelidae), an oligophagous herbivore of dock (Rumex spp.) (Martinkova \& Honek, 2004), was first reported in Bohemia (now the western part of the Czech Republic) in the mid-1800s (Lokaj, 1869). The original area of its occurrence were the Alpine regions (Kuhnt, 1911; Reitter, 1913) from which this "paleoinvasive" species spread into lowland areas in Central Europe. In Bohemia, this was well documented, and when first recorded in the mid-1800s, this species was very rare and present only in the highlands (Lokaj, 1869). Since then, it has spread throughout Central Europe (Franck, 1935) and by the 1950s, it was abundant in dock stands throughout the Czech Republic (Balthasar, 1957). This may have been supported by the spread of Rumex spp., which occurred as a result of changes implemented after the collectivization of agriculture in the early 1950s (Klimeš, 1989; Martinkova \& Honek, 2004). Gastrophysa viridula is considered to be an important factor in the biological control of Rumex in pastures and managed grasslands (Bentley et al., 1980; Cottam et al., 1986; Grossrieder \& Keary, 2004).

The life cycle of $G$. viridula is well known (Remaudière, 1948; Engel, 1956). In Central Europe adults overwinter and beginning at the end of April, females start to lay yellow eggs on the abaxial side of the leaves. The black larvae of the first instar remain aggregated at the sites of egg clusters and eat the lower leaf epidermis and mesophyll. The second- to third-instar larvae disperse to other leaves and skeletonize the lamina. Pupation and the development of pupae takes place in the soil. After eclosion, the adults leave the soil, climb the stems of dock and repeat the developmental cycle. At $18^{\circ} \mathrm{C}$, preimaginal development lasts 28 days, the median adult lifespan is 33 days (Honek et al., 2003) and the species has 2-3 generations a year (Swatonek, 1972; Whittaker, 1982). 
A precondition for the successful development of larvae is the availability of fresh leaves (Engel, 1956; Smith \& Whittaker, 1980a). When laying eggs, females avoid old leaves, leaves damaged by the rust Uromyces rumicis (Schumacher) (Hatcher et al., 1995) and leaves previously occupied by conspecific larvae (Weingartner et al., 1997). Survival of the G. viridula population in a dock stand is therefore supported by mowing, which removes senescent shoots and promotes regrowth of new shoots (Van Evert et al., 2020). Larvae and adults that drop to the ground during mowing and survive on ground leaf rosettes, later colonize regrown fertile shoots and continue the population at a site. Continuation of a local population is vital because females with abdomens swollen with eggs move with difficulty and are unable to fly or walk even for a short distance (Renner, 1970; Smith \& Whittaker, 1980b). Colonization of new dock stands is slow and G. viridula populations are highly localized, and their survival depends on conducive local conditions.

In this paper, we report the unprecedented decline of this species in Bohemia during the last ca. 20 years. We first recorded the presence of G. viridula in dock stands in 19951999. The purpose of this investigation was to determine whether herbivory of $G$. viridula affects the dormancy of dock seeds (Martinkova \& Honek, 2000). At this time, $G$. viridula was a widespread and very abundant species. We were not able to examine the expected differences because G. viridula was present in all local stands. In contrast, our recent sampling in early 2019 showed that $G$. viridula populations occurred only in a minority of dock stands, and in most occupied stands, this species was rare. This striking difference in the past and recent occurrence of this species led us to a detailed investigation of the presence and abundance of G. viridula in local dock stands from 2019-2020.

\section{MATERIALS AND METHODS}

The presence of G. viridula was determined in "local stands" of Rumex obtusifolius L., which are defined as a group of dock plants growing in an area $\leq 2500 \mathrm{~m}^{2}$ at least $200 \mathrm{~m}$ away from another stand included in this study.

From 1995-1999, local stands of R. obtusifolius were first visited in spring or summer, and the presence/absence of G. viridula recorded. A total of 177 local stands of $R$. obtusifolius, located between $49.52-50.61^{\circ} \mathrm{N}$ and $12.48-16.49^{\circ} \mathrm{E}$ at 150 to $1060 \mathrm{~m}$ a.s.1., in grasslands and road margins, were visited.

In the pilot investigation in 2019, it was found that the local stands monitored from 1995-1999 no longer existed. Therefore, it was not possible to compare the presence of $G$. viridula in both periods at the same localities. From 2019-2020, we therefore detected the presence of $G$. viridula in 434 new local dock stands. In each of these stands, we recorded the presence of $G$. viridula on individual plants. All plants were inspected in local stands with $<150$ plants, while in larger stands, $\geq 100$ plants were inspected. On each plant, both sides of all leaves of the ground rosette and fertile shoots were inspected, and the frequency of plants infested with eggs and/or larvae was recorded. According to the frequency of infested plants, local dock stands were classified into four categories based on the value of $\ln (n+1)$, where $n$ is the percentage of occupied plants in a local population. This criterion was used to classify local stands into four categories: (i) very scarcely infested stands with $\leq 2 \%$ of plants occupied by $G$. viridula, (ii) scarcely

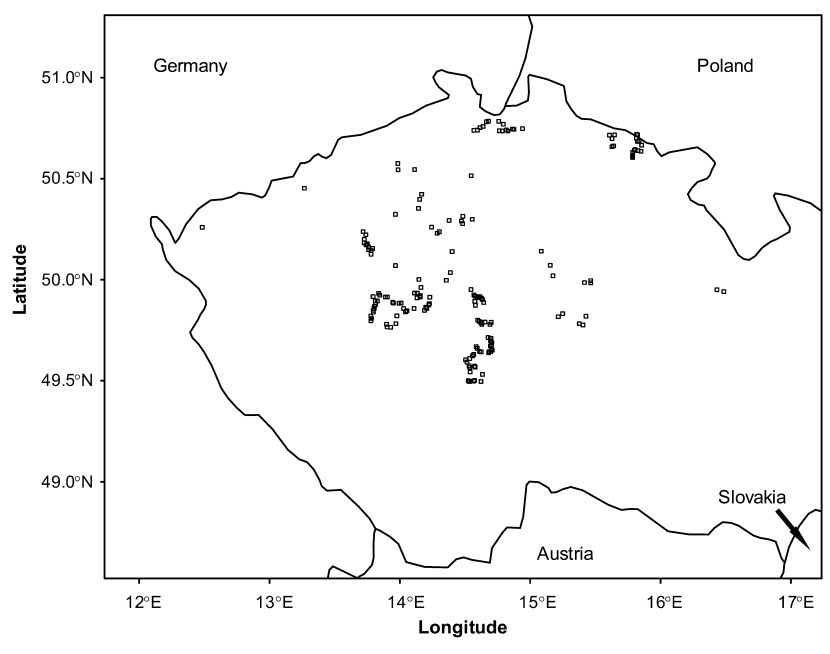

Fig. 1. Geographic location of the stands of $R$. obtusifolius visited from 1995-1999. $\square$ stands where G. viridula was present.

infested stands with $3-19 \%$ of plants occupied, (iii) abundantly infested stands with $20-54 \%$ of plants occupied and (iv) heavily infested stands with $\geq 55 \%$ of plants occupied. The dock stands were located in four areas that differed in terms of landscape ruggedness and climate: the Elbe River Valley, which is a flat area at $49.89-50.77^{\circ} \mathrm{N}, 14.04-15.83^{\circ} \mathrm{E}$ where 102 local dock stands at altitudes between 130-275 m were visited; the Prague Plateau, which is an undulating area at $50.06-50.21^{\circ} \mathrm{N}, 14.02-14.42^{\circ} \mathrm{E}$ where 68 dock stands at altitudes between $180-420$ m were visited; the Ralská pahorkatina and Lužické hory highlands, which are a volcanic hilly area at $50.66-50.84^{\circ} \mathrm{N}, 14.41-14.98^{\circ} \mathrm{E}$, where 116 dock stands at altitudes between $280-770 \mathrm{~m}$ were visited; and the Benešovská and Vlašimská pahorkatina highlands, which are an eroded highland area at $49.42-49.88^{\circ} \mathrm{N}, 14.45-15.01^{\circ} \mathrm{E}$, where 121 dock stands at altitudes between $300-630 \mathrm{~m}$ were visited. Outside these areas, we visited 27 dock stands at altitudes between 300-680 $\mathrm{m}$.

Differences in the frequency of stands occupied by G. viridula from 1995-1999 and 2019-2020 were tested using $2 \times 2$ contingency tables and chi-square tests. The change in the percentage of plants infested by G. viridula in dock stands relative to altitude and changes in average annual temperature from year to year were fitted by linear regression.

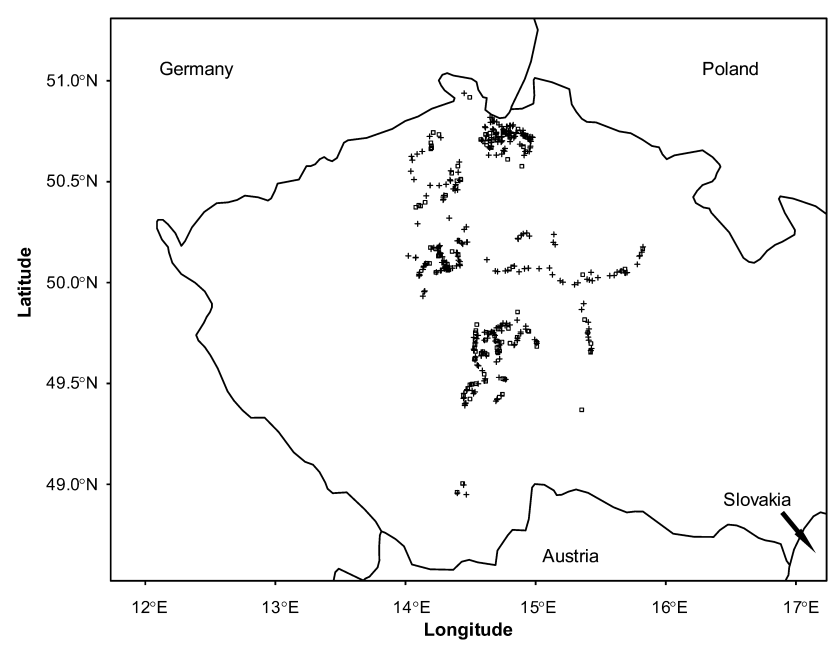

Fig. 2. Geographic location of stands of $R$. obtusifolius visited from 2019-2020. $\square$ stands where G. viridula was present, + stands where $G$. viridula was absent. 


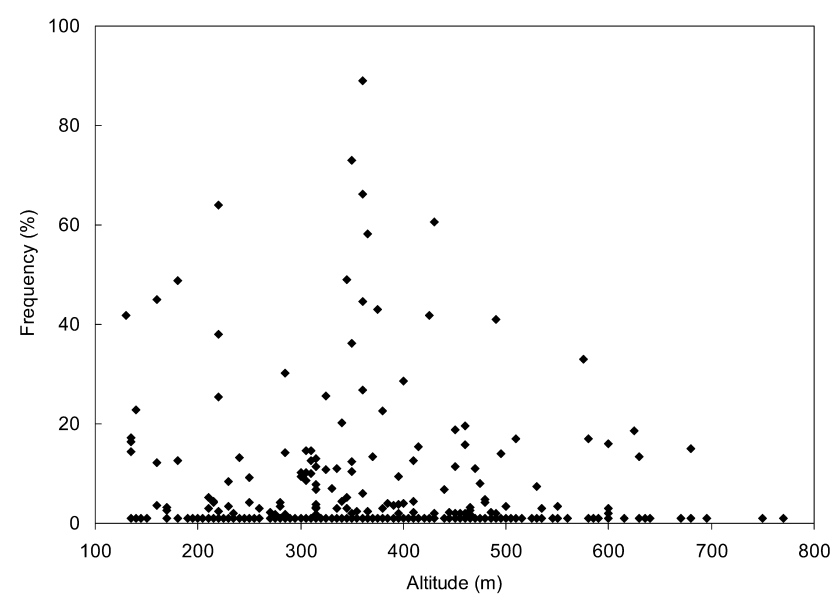

Fig. 3. The relationship between the frequency $(n+1 \%)$ of local stands of $R$. obtusifolius plants infested with $G$. viridula and altitude of each stand. Regression: $y=-0.0022 x+5.6375, R^{2}=0.0006$, N.S.

\section{RESULTS}

From 1995-1999 (Fig. 1), G. viridula occurred in all 177 local stands of $R$. obtusifolius visited. From 2019-2020 (Fig. 2), it was found in 126 (29\%) out of 434 local stands, which was significantly less than that in the late $1990 \mathrm{~s}\left(\chi^{2}=\right.$ $253.3, \mathrm{P}<0.005)$. Of the infested stands, $52(12 \%)$ were in category (i) and thus very scarcely infested, 25 stands $(6 \%)$ were in category (ii), 33 stands ( $8 \%$ ) in category (iii) and 16 stands (3\%) in category (iv) and thus heavily infested with $G$. viridula. Local stands populated with $G$. viridula and stands where it was absent were scattered evenly over the area investigated (Fig. 2). No relationship was found between the abundance of $G$. viridula and altitude of the localities of the dock stands (Fig. 3).

\section{DISCUSSION}

This study demonstrated that the frequency of stands infested with $G$. viridula was significantly higher in the 1990s than from 2019-2020. This result is important because it records the decline of an invasive (although long naturalized) species. In the Czech Republic, there are reports of cases of invasion and later declines for several arthropod species. A recent case is an aphid, Diuraphis noxia (Kurdjumov) (Homoptera: Aphididae), which spread in the Czech Republic in the early 1990s (Stary, 1996; Stary et al., 2003) and was nearly absent by 2010 (Havelka et al., 2014). The invasion of the spider Lycosa singoriensis (Laxmann) (Araneae: Lycosidae), which colonized the eastern part of the Czech Republic in 1924 and was completely absent by 1970 , is documented in detail (Řezáč et al., 2015). Unlike G. viridula, the above species did not colonize the whole of the Czech Republic and they were only present for a short period.

The decline of G. viridula in the Czech Republic is based on data collected in two periods 20-years apart. In each period, a number of sites spread over a large area were sampled. The significant difference between the two periods in the frequency of occupied stands and (probably) in the abundance of individuals indicates a decrease in the presence of this species. As the data were collected at different times it could be argued that the difference was due to the population being in opposite phases of a periodic oscillation in population density (Didham et al., 2020), but we assume that this is not the case. Population oscillations usually manifest themselves as temporary increases in species abundance (Varley, 1949; Ruohomaki et al., 2000; Moreau, 2006) rather than the long-term "drop" recorded in this study.

The causes of the decline in G. viridula remain a matter of speculation. We assume that two factors might have been involved: climate warming and fragmentation and relocation of dock stands. The assumption that the decline might be affected by climate change is discussed first because it is in line with the prevailing belief in the significant influence of this factor on insect population dynamics (Robinet \& Roques, 2010; Halsch et al., 2021).

Climate warming is an important source of current environmental change (Anonymous, 2019), which can promote both the spread of species into new areas and contribute to their decline (Gutierrez \& Ponti, 2014; Iannella et al., 2020). Since the 1980s, the average annual temperature in Prague, the centre of the region studied, has increased by $0.06^{\circ} \mathrm{C}$ per year (Anonymous, 2004, 2010, 2020), which is similar to what has occurred throughout this country (Matejka, 2019). There was no trend in the quantity of precipitation, but 2003-2009 and 2014-2019 were dry periods with the amount of precipitation below the 1980-2019 average. The warm and dry period after 2000 may have negatively affected the survival of $G$. viridula, as this was originally an alpine species (Kuhnt, 1911; Reitter, 2013) and is likely to thrive better in cold/mild and humid climates than in warm and dry climates. However, the effect of temperature on the fitness and viability of $G$. viridula is unknown.

A direct negative effect of an increase in temperature on $G$. viridula cannot be assumed. The reactions of this species to temperature were studied by Honek et al. (2003), who demonstrate that this species thrives at temperatures as high as $28^{\circ} \mathrm{C}$. Although longevity is shorter, the number of eggs laid is not different and the intrinsic rate of population increase is higher than at lower temperatures $(18,21.5$ and $25^{\circ} \mathrm{C}$ ).

We therefore hypothesize that an increase in temperature is more likely to affect $G$. viridula by reducing the quality of its host plant. This might accelerate the ageing of dock plants and thus threaten the success of the development of the second and third generations, resulting in a decrease in the abundance or even extinction of $G$. viridula populations. Rejuvenation of aboveground parts of the dock is supported by mowing. However, mowing is only regularly carried out in meadows, edges of roads and when maintaining lawns in housing estates. Many dock stands are thus no longer regularly mown and are therefore unsuitable for the survival of $G$. viridula.

In our opinion, another important cause of the decline in $G$. viridula is the fragmentation of formerly large stands of dock and extinction of their remnants. The fragmenta- 
tion and extinction of dock stands are occurring because farming methods have changed, specifically the replacement of mowed grasslands with pastures (Zaller, 2006; Hejcman et al., 2014) and the decrease in the application of $\mathrm{N}$ fertilizers to grasslands (Foster, 1989). An example is the fragmentation of large stands of R. obtusifolius in the grasslands bordering the upper course of the Lužnice River between $48.81-48.89^{\circ} \mathrm{N}$ and $14.88-14.94^{\circ} \mathrm{E}$ recorded by Klimeš (1989). An area approximately $4 \mathrm{~km}^{2}$ large was divided into $100 \times 100 \mathrm{~m}$ squares, and dock abundance was recorded in each square. In 2020, a $0.36 \mathrm{~km}^{2}$ part of this area was re-examined on the right bank of the Lužnice River, between 48.8667-48.8806 ${ }^{\circ} \mathrm{N}$ and $14.8871-$ $14.8967^{\circ} \mathrm{E}$ (Z. Martinkova \& A. Honek, unpubl.). This area was overgrown with dock in the 1980s, and in 2020, dock was confined to a few small stands separated by grassland.

The developments of new dock stands at sites far from stands already populated by $G$. viridula also increases the proportion of unoccupied dock stands. The newly developing stands in urban green areas are hard for $G$. viridula to access. They are often scattered in urban and suburban areas on lawns or reclaimed road margins, which are far from stands where $G$. viridula is still present. To sustain these populations, frequent recolonization of new habitats is needed, but in most areas there are now very few or no source populations.

This paper provides a rare documentation of the decline of an invader. The reasons for the decline, however, need further investigation. Possible causes of the reduction in the abundance of $G$. viridula are the joint effects of climate warming and changes in agricultural practices on the quality of its host plant, the fragmentation and extinction of stands of dock and the inability of $G$. viridula to colonize new stands of dock created by humans.

ACKNOWLEDGEMENTS. We thank L. Kreslova, H. Uhlirova and J. Kohoutova for excellent technical assistance. The work was supported by Institutional Support RO 0418.

\section{REFERENCES}

Anonymous 2004: Statistical Yearbook of the Czech Republic 2004. URL: https://www.czso.cz/ csu/czso/statisticka-rocenkaceske-republiky-2004-osy4e1rfig (last accessed 20 Jun. 2021) [in Czech].

Anonymous 2010: Statistical Yearbook of the Czech Republic 2010. URL: https://www.czso.cz/ csu/czso/statisticka-rocenkaceske-republiky-2010-zqa20b153r (last accessed 20 Jun. 2021) [in Czech].

Anonymous 2019: Global and European Temperature. European Environment Agency. URL: https://www.eea.europa.eu/dataand-maps/indicators/global-and-european-temperature/globaland-european-temperature-assessment-5 (last accessed 20 Jun. 2021).

Anonymous 2020: Statistical Yearbook of the Czech Republic 2020. URL: https://www.czso.cz/ csu/czso/statisticka-rocenkaceske-republiky-2020 (last accessed 20 Jun. 2021) [in Czech].

Balthasar V. 1957: Order Beetles - Coleoptera. In Kratochvíl J. (ed.): Key of the Fauna of ČSR. Part II. Czechoslovak Academy of Sciences, Praha, pp. 419-703 [in Czech].

Bentley S., Whittaker J.B. \& Malloch A.J.C. 1980: Field experiments on the effect of grazing by a chrysomelid beetle (Gas- trophysa viridula) on seed production and quality in Rumex obtusifolius and Rumex crispus. — J. Ecol. 68: 671-674.

Bradshaw C.J.A., leroy B., Bellard C., Roiz D., Albert C., Fournier A., Barbet-Massin M., Salles J.M., Simard F., Courchamp F. 2016: Massive yet grossly underestimated global costs of invasive insects. - Nature Commun. 7: 12986, 8 pp.

Cottam D.A., Whittaker J.B. \& Malloch A.J.C. 1986: The effect of chrysomelid beetle grazing and plant competition on the growth of Rumex obtusifolius. - Oecologia 70: 452-456.

Didham R.K., Basset Y., Collins C.M., Leather S.R., Littlewood N.A., Menz M.H.M., Müller J., Packer L., Saunders M.E., SchönRogGE K. ET AL. 2020: Interpreting insect declines: seven challenges and a way forward. - Insect Conserv. Diver. 13: 103-114.

ENGEL H. 1956: Beiträge zur Lebensweise des Ampferblattkäfers (Gastrophysa viridula Deg.). — Z. Angew. Entomol. 38: 323354.

FOSTER L. 1989: The biology and non-chemical control of dock species Rumex obtusifolius and R. crispus. - Biol. Agric. Hortic. 6: 11-25.

FRANCK P. 1935: Zur Verbreitung der Gastroidea viridula Deg. in Deutschland in älterer und neuerer Zeit. — Entomol. Blätter 31: 51-55.

Grossrieder M. \& Keary I.P. 2004: The potential for the biological control of Rumex obtusifolius and Rumex crispus using insects in organic farming, with particular reference to Switzerland. - Biocontr. News Inform. 25(3): 65N-79N.

Gutierrez A.P. \& Ponti L. 2014: Analysis of invasive insects: links to climate change. In Ziska L.H. \& Dukes J.S. (eds): Invasive Species and Global Climate Change. CABI, Wallingford, pp. 45-61.

Halsch C.A., Shapiro A.M., Fordyce J.A., Nice C.C., Thorne J.H., WaetJen D.P. \& Forister M.L. 2021: Insects and recent climate change. - Proc. Natl. Acad. Sci. 118(2): e2002543117, 9 pp.

Havelka J., Zurovcova M., Rychly S. \& Stary P. 2014: Russian wheat aphid, Diuraphis noxia in the Czech Republic - cause of the significant population decrease. - J. Appl. Entomol. 138: 273-280.

Hejcman M., Strnad L., Hejcmanova P. \& Pavlu V. 2014: Biological control of Rumex obtusifolius and Rumex crispus by goat grazing. - Weed Biol. Manag. 14: 115-120.

HoneK A., JarosiK V. \& Martinkova Z. 2003: Effect of temperature on development and reproduction in Gastrophysa viridula (Coleoptera: Chrysomelidae). — Eur. J. Entomol. 100: 295300 .

IAnNella M., D’Alessandro P. \& Biondi M. 2020: Forecasting the spread associated with climate change in Eastern Europe of the invasive Asiatic flea beetle, Luperomorpha xanthodera (Coleoptera: Chrysomelidae). — Eur. J. Entomol. 117: 130138.

Kenis M., Auger-Rozenberg M.A., Roques A., Timms L., Péré C., Cock M.J.W., Settele J., Augustin S. \& Lopez-Vaamonde C. 2009: Ecological effects of invasive alien insects. - Biol. Invas. 11: 21-45.

KLIMEŠ L. 1989: Distribution and ecological differentiation of broad-leaved docks (Rumex L.) in the floodplain of Lužnice river, South Bohemia, Czechoslovakia. — Preslia 61: 129-144 [in Czech, English abstract].

KuHNT P. 1911: Illustrierte Bestimmungstabellen der Käfer Deutschlands. E. Schweizerbart'sche Verlagsbuchhandlung Erwin Nägele, Stuttgart, 1138 pp.

Lincoln R., Boxshall G. \& Clark P. 1998: A Dictionary of Ecology, Evolution and Systematics. Cambridge University Press, Cambridge, UK, 361 pp. 
LoKaJ E. 1869: Verzeichniss der Käfer Böhmens. - Arch. Naturw. LandDurchforsch. Böhm. 1 (Abteilung IV, Zoologie): $1-77$.

MartinKova Z. \& HoneK A. 2000: Variation in the germination of seeds of Rumex obtusifolius in the Czech Republic. - Plant Prot. Sci. 36: 101-106.

MartinKova Z. \& HoneK A. 2004: Gastrophysa viridula (Coleoptera: Chrysomelidae) and biocontrol of Rumex - a review. Plant Soil Environ. 50: 1-9.

Martinkova Z., Honek A., Pekar S. \& Strobach J. 2009: Survival of Rumex obtusifolius L. in an unmanaged grassland. Plant Ecol. 205: 105-111.

MatEJKA K. 2019: [Changes of Temperatures and Precipitations in the Czech Republic since 1961.] URL: http://www.infodatasys.cz/climate/klimaCR1961.htm (last accessed 20 Jun. 2021).

Moreau G. 2006: Past and present outbreaks of the balsam fir sawfly in western Newfoundland: An analytical review. Forest Ecol. Manag. 221: 215-219.

Reitter E. 1913: Fauna Germanica. Die Käfer des Deutschen Reiches. Band IV. K.G. Lutz, Stuttgart, 236 pp.

RenNER K. 1970: Zur Fortpflanzungsbiologie und Embryonalentwicklung von Gastroidea viridula Deg. (Col.: Chrysomelidae). -Zool. Anz. 185: 274-283.

Řezáč M., Macík S., Dolanský J., Henriques S., Chvátalová I., Korba J., Korenko S., Macek R., Šnajdara P., Vinkler S. ET AL. 2008: The return of the tarantula or Lycosa singoriensis again in the Czech Republic. — Živa 2008(1): 25-27 [in Czech].

Robinet C. \& Roques A. 2010: Direct impacts of recent climate warming on insect populations. - Integrat. Zool. 5: 132-142.

Roy H.E., Bacher S., Essl F., Adriaens T., Aldridge D.C., Bishop J.D.D., Blackburn T.M., Branquart E., Brodie J., CarbonERAS C. ET AL. 2019: Developing a list of invasive alien species likely to threaten biodiversity and ecosystems in the European Union. - Global Change Biol. 25: 1032-1048.

Ruohomaki K., Tanhuanpaa M., Ayres M.P., Kaitaniemi P., TamMARU T. \& HAUKIOJA E. 2000: Causes of cyclicity of Epirrita autumnata (Lepidoptera, Geometridae): grandiose theory and tedious practice. - Popul. Ecol. 42: 211-223.
Salt D.T. \& WhitTaKer J.B. 1998: Insects on Dock Plants. Naturalists' Handbooks 26. The Richmond Publishing, Slough, UK, $56 \mathrm{pp}$.

Smith R.W. \& Whittaker J.B. 1980a: Factors affecting Gastrophysa viridula populations (Coleoptera: Chrysomelidae) in different habitats. - J. Anim. Ecol. 49: 537-548.

SMith R.W. \& WhitTaKeR J.B. 1980b: The influence of habitat type on the population dynamics of Gastrophysa viridula DeGeer (Coleoptera: Chrysomelidae). - J. Anim. Ecol. 49: 225-236.

Stary P. 1996: The expansive Russian wheat aphid, Diuraphis noxia (Mordw) detected in the Czech Republic. - Anz. Schadlingsk. Pflsch. Umwsch. 69: 19-20.

Stary P., Basky Z., Tanigoshi L.K. \& Tomanovic Z. 2003: Distribution and history of Russian wheat aphid, Diuraphis noxia (Kurdj.) in the Carpathian Basin (Hom., Aphididae). - Anz. Schadlingsk. Pflsch. Umwsch. / J. Pest Sci. 76: 17-21.

Swatonek F. 1972: Ein Beitrag zur Biologie des Ampferblattkäfers (Gastroidea viridula Deg.). — Anz. Schadlingsk. Pflsch. Umwsch. 45: 116-119.

Van Evert F.K., Cockburn M., Beniers J.E. \& Latsch R. 2020: Weekly defoliation controls but des not kill broad-leaved dock (Rumex obtusifolius). — Weed Res. 60: 161-170.

VARLEY G.C. 1949: Population changes in German forest pests. - J. Anim. Ecol. 18: 117-122.

Weingartner M., SChindek R. \& Hilker M. 1997: Intraspezifische Interaktionen zwischen Larvae und Imagines des Blattkäfers Gastrophysa viridula (Coleoptera, Chrysomelidae). Mitt. Dt. Ges. Allg. Angew. Entomol. 11: 491-493.

WhitTAKeR J.B. 1982: The effect of grazing by a chrysomelid beetle, Gastrophysa viridula, on growth and survival of Rumex crispus on a shingle bank. - J. Ecol. 70: 291-296.

ZALLER J.G. 2006: Sheep grazing vs. cutting: regeneration and soil nutrient exploitation of the grassland weed Rumex obtusifolius. - BioControl 51: 837-850.

Received June 23, 2021; revised and accepted August 27, 2021 Published online September 13, 2021 